\title{
Informal Financial Institutions (IFIs) and Poverty Reduction in Konshisha Local Government Area of Benue State, Nigeria
}

\author{
Beeior, C. $T^{1^{*}---}$ Ajegi, S.O $O^{2}---$ Tyoakosu, J. $A^{3}$. \\ ${ }^{1}$ Department of Agricultural Education, College of Education Oju, Benue State, Nigeria \\ ${ }^{2}$ Department of Economics, Benue State University, Nigeria \\ ${ }^{3}$ Department of Economics College of Education Oju, Benue State Nigeria
}

\begin{abstract}
This study was carried out to examine the impact of informal financial institutions (IFIs) on poverty reduction in Konshisha local government area of Benue State, Nigeria. A total of 220 questionnaires were administered to households in the study area; 110 each for beneficiaries and non-beneficiaries of informal financial institutions (IFIs) in the study area. Data collected were analyzed using P-Apha, logit regression model, simple percentages and T-test statistics. The result showed that the incidences of poverty $\left(\mathrm{p}_{\mathrm{o}}\right)$, depth $\left(\mathrm{P}_{1}\right)$ and severity $\left(\mathrm{P}_{2}\right)$ were found to be worse among the non-beneficiaries of IFIs. The result of T-test of difference in mean of real household consumption-Expenditure of beneficiaries \& non- beneficiaries of IFIs also indicated clearly that beneficiaries of IFIs have more real household consumption expenditure than non-beneficiaries of IFIs in the study area. The result of the Logit regression model showed that out of the seven variables regressed, only three namely: averages monthly savings, education \& household size have influenced significantly the poverty status of the respondents at $5 \%$ level. The study identified shortage of funds for disbursement to members as the major problem hindering the smooth operation of IFIs in the study area. It was suggested among other recommendations that government and other relevant organizations should provide soft loans to members of IFIs through the IFIs in which they belong to expand their small businesses and hence reduce their poverty level.
\end{abstract}

Keywords: Poverty, Reduction, Informal financial institutions (IFIs), Konshisha, Benue and Nigeria.

\section{Contents}

1. Introduction

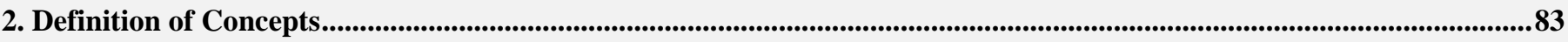

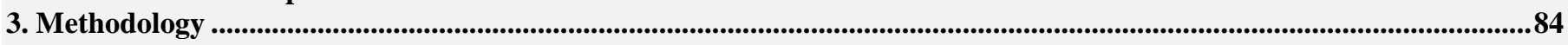

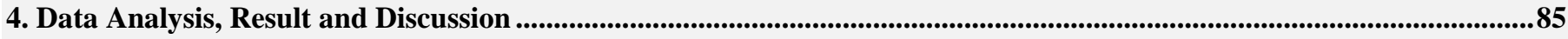

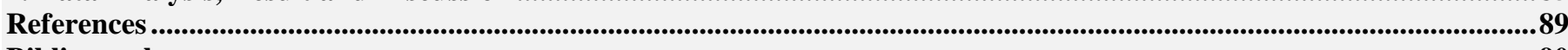

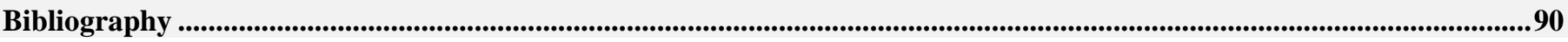

Citation | Beeior, C. T; Ajegi, S.O; Tyoakosu, J. A. (2016). Informal Financial Institutions (IFIs) and Poverty Reduction in Konshisha Local Government Area of Benue State, Nigeria. Asian Journal of Social Sciences and Management Studies, 3(1): 82-90.

DOI:

$\operatorname{ISSN}(\mathbf{E})$ :

$\operatorname{ISSN}(\mathbf{P}):$

Licensed:

Contribution/ Acknowledgment:

Funding:

Competing Interests:

Transparency:

Ethical:

History:

Publisher: 10.20448/journal.500/2016.3.1/500.1.82.90

2313-7401

2518-0096

This work is licensed under a Creative Commons Attribution 3.0 License $($ (c) $)$ EY

All authors contributed to the conception and design of the study.

This study received no specific financial support.

The authors declare that they have no conflict of interests.

The authors confirm that the manuscript is an honest, accurate, and transparent account of the study was reported; that no vital features of the study have been omitted; and that any discrepancies from the study as planned have been explained.

This study follows all ethical practices during writing.

Received: 2 July 2015/ Revised: 1 August 2015/ Accepted: 27 October 2015/ Published: 8 November 2015 Asian Online Journal Publishing Group 


\section{Introduction}

Nigeria is endowed with numerous resources found in different states of the federation. It also has fertile arable land for agricultural production. In spite the abundance of these resources, there is still a great deal of poverty ravaging Nigerian particularly the rural people (Ajegi, 2004).

The federal government has in line with the global convention, been trying to ameliorate the worsening condition of the poor, by directing public expenditure towards poverty reduction programmes and projects to cushion the effects of poverty in the country. These programmes include the directorate of food, roads and rural infrastructure (DFRRI), Better life Programme (BLP), Family Support Programme (FSP), National Directorate of Employment (NDE), Family Economic Advancement Programme (FEAP), National Agricultural Land Development Authority (NALDA), National Agency for mass literacy, the people's Bank of Nigeria, the Federal Urban Mass Transits Programme, Nigerian Agricultural and rural development Bank just to mention but a few.

In spite of the huge resources devoted to poverty reduction, deterioration in fiscal discipline, corruption, political instability and inconsistent policies undermined past efforts, thus making poverty reduction in Nigeria a paradox. The level of unemployment continue to rise, inequality gap continues to widen (the rich becoming richer and the poor becoming poorer), while poverty conditions are exacerbated. A World Bank estimate on the level of poverty in Nigeria indicates that 70.2 percent of the country's population live below the poverty line, the majority of this number is found in the rural areas and that the scourge will continue to rise if nothing is done to arrest it World Bank (1990). This bizarre picture requires an urgent intervention, which the study on the informal financial institution is one.

According to Aliyu (2002) all the poverty Alleviation programmes that Nigerians have had dangled before their eyes since independence in 1960, have failed woefully or yielded very little fruits due to reasons earlier mentioned above.

Most of these poverty reduction programmes were aimed at providing income capital to the rural poor to burst their investment capabilities to reduce poverty. However, the rural people who are the most poor and expected to be real beneficiaries of such programmes in most cases are unable to access them. This frustrating situation have made some of these rural poor to alternatively come together and involve themselves in self help groups known as informal financial institutions (IFIs) in order to access investment funds to reduce their poverty level. The situation of Konshisha local government area which is basically a rural community is not different from other rural communities in Nigeria. But the question is to what extent has informal financial institutions in Konshisha Local government Area contributed to poverty reduction in respect to jobs creation and provision of income opportunities.

It is against this background that this research work is embarked upon to ascertain the contribution of various informal financial institutions to poverty reduction of households who are members of these institutions in Konshisha local government area with the view of examining the socio economic attributes influencing the poverty level of the people in the study area.

\section{Definition of Concepts}

The term poverty means so many things to so many people under different situations. Awolowo (1981) described poverty as "the absence or lack of basic necessities of life or lack of command over basic consumption needs such as food, clothing and shelter',

There are so many other definitions of the concept of poverty but for the purpose of this study, the researchers define poverty as a situation where an individual's real household consumption-expenditure is below 63875 Naira per adult/ annum. This definition implies that once a respondent's annual consumption expenditure is below the above poverty line, he/she is considered being poor. While Informal financial institutions (IFIs) can be defined as local arrangement for savings and credit which are unregistered and not controlled by the government but operate with an oath of allegiance and mutual trust.

Beneficiaries of Informal Financial Institutions: This refers to people who are members of informal financial institutions in the study area.

Non-Beneficiaries of Informal Financial Institutions: These are non-members of Informal Financial Institutions (IFIs) and hence have never benefitted from these institutions in the study area.

Konshisha: This is the name of one of the local government councils in Benue State Nigeria, where the research work was carried out.

\subsection{Theoretical Review}

This research work is based on two theories: vicious circle of poverty and financial repression theories:

The financial repression theory (Mckinnon, 1973; Shaw, 1973) views informal finance as a result of state intervention in financial markets through a set of regulations and restrictions. Instruments of financial regulations include among other things, interest rate ceiling, high liquidity ratio requirement, high bank reserve requirements, capital and credit control and restrictions on market entry..... All these policies have a great potential of discouraging savings while reducing supply of credit by formal financial institutions. As a consequence some individuals are prevented from accessing credit, even though without these regulations they qualify for obtaining formal credits. The resulting unsatisfied demand is therefore, absorbed by the unorganized informal money markets which act as a residual market such as to allow financial market clear. It is implicitly assumed that informal financial markets are easily accessible.

Vicious Circle of Poverty: This theory emphasized the link between lack of capital and under development. The theory can be used at both national and individual levels, but we concentrated on the individual level in this research work.

However, the vicious circles operate both on demand side and the supply side, the demand side of the vicious circle is that the low level of real income leads to low level of demand which is in turn leads to a low rate of investment resulting to deficiency of capital, low productivity and low income. While the supply side of the vicious circle holds that low level of real income means low saving which leads to low investment and deficiency of capital. 
The deficiency of capital in turn leads to a low level of productivity and back to low income. This theory is adopted for this study because many rural communities in Nigeria are poor due to lack capital to increase productivity resulting to low income and saving.

\section{Methodology}

This study was conducted in Konshisha local government area of Benue State, Nigeria. The local government is an agrarian community with large percentage of the populace engaged in farming and agro-allied activities.

The population for this study is made up of all the informal financial institutions in Konshisha local government (256 IFIs) comprising 14,184 members compiled across the eleven council wards of the local government during pre-survey stage of the study. One informal financial institution was selected from each of the eleven council wards of the local government to have a total number of eleven IFIs giving a total population of 1,604 members for the study. Ten (10) respondents were then randomly sampled from each of the eleven (11) purposely selected IFIs across all the eleven council wards in the study area for completion. The same numbers of respondents were also randomly sampled for non-beneficiaries of IFIs in the same area. These two samples gave a desired sample size of 220 respondents considered for analysis.

The data collected for this study was analyzed using both descriptive and inferential statistics. The description statistics includes mean, standard deviation, frequency, percentages and dollar per day measure of poverty. While adult equivalent scale, popular P-alpha class of poverty measure and logit regression served as inferential tools.

\subsection{The Adult Equivalent Scale}

This scale was used to obtain the real household consumption-expenditure of the respondents. It is recommended by the Organization for Economic Cooperation and Development (OECD) and was used by Noah et al. (2009). It is adopted in this research work due to it's simplicity of use. It is expressed as follows:

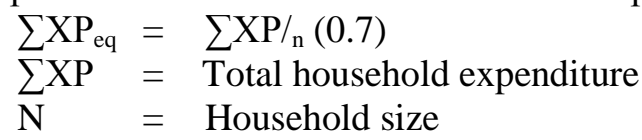

$0.7=$ Exponential formation representing other adults in a particular household (Grootaert and Braithwaite, 1998).

\subsection{Dollar per Day Measure of Poverty}

Dollar per day was used as poverty line to separate the poor from the non-poor during data analysis. Poverty line is an arbitrary divider of the poor from the non poor (Federal of Statistics (F.O.S), 1999). To delineate the poor from the non- poor, a minimum acceptable threshold to measure the standard of living of the people was established. People were counted as poor when they fell below such a minimum acceptable threshold (Appleton, 2001). A minimum annual consumption expenditure of $\mathbf{6 3 8 7 5}$ naira per adult/annum was adopted to separate the poor from the non-poor. Those who fell below this expenditure threshold were considered poor. The above value was obtained by multiplying the average exchange rate in the year 2014 by the number of days in a year

\subsection{P-Alpha}

$P$-Alpha was used to determine the incidence $\left(\mathrm{P}_{\mathrm{o}}\right)$, the depth $\left(\mathrm{P}_{1}\right)$ and severity of poverty $\left(\mathrm{P}_{2}\right)$ in the study area, (Foster et al., 1984).The measure relates to dimensions of incidence of poverty; $\mathrm{p}_{0} \mathrm{p}_{1} \& \mathrm{p}_{2}$ defined as:

$P_{0}=\quad$ Head count/incidence of poverty: This count the number of people with expenditure below the poverty line.

$P_{1}=\quad$ Depth of poverty: This is the percentage of expenditure/Income required to bring each individual below the Poverty line up to the poverty line

$P_{2}=\quad$ Severity of poverty: This is indicated by giving longer weight to the extremely core poor. It achieved by squaring the gap between their expenditure/ income and poverty increases its weight in the overall poverty measure.

Mathematically, $P$-Alpha can be expressed as:

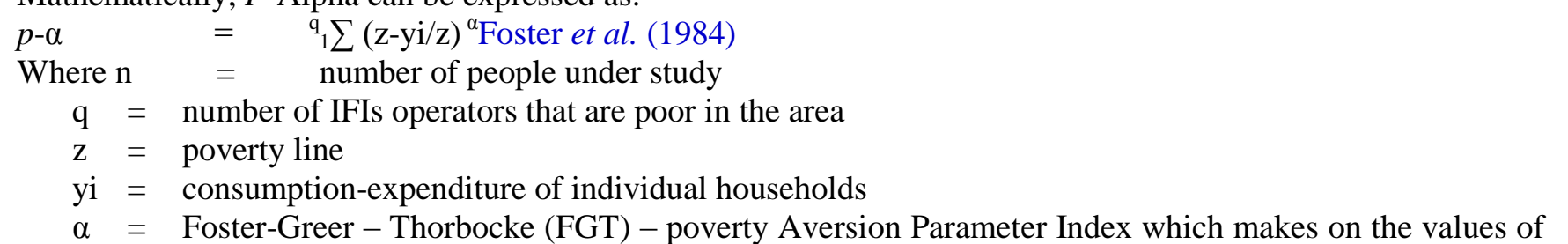
0,1 and 2 representing incidence of poverty, poverty gap and severity of poverty respectively.

$\left[\frac{z-y i}{z}\right]=$ The proportionate short fall of expenditure/income below the poverty line. The quantity is raised

to a power of $\alpha$. If $\alpha=0$, the FGT becomes $\mathrm{P}_{\mathrm{o}=}{ }_{n}^{1 /} \mathrm{q}=$ which is the proportion of the population, that falls below the poverty line. This is called the head count or incidence of poverty.

$$
\begin{aligned}
& \text { If } \alpha=1 \text { FGT becomes } \\
& P_{1}=1 / \mathrm{n} \sum_{\mathrm{i}=1^{-}} \alpha\left[\frac{z-y}{z}\right] \\
& \text { If } \alpha=2 \text { FGT becomes } \\
& P_{2}=1 / \mathrm{n} \sum_{\mathrm{i}=1} \alpha\left[\frac{z-y}{z}\right]^{2}
\end{aligned}
$$




\subsection{Model Specification}

A logit regression model was used. The model uses socio-economic variables of the respondents to determine the factors influencing poverty. Ramakrishma and Demeke (2002) implicitly expressed the model as:

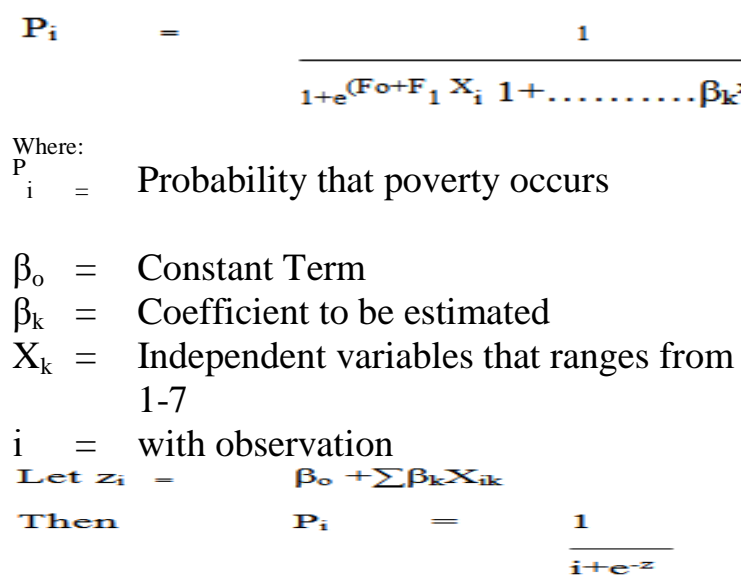

As $Z_{i}$ ranges from $-\alpha,+\alpha, P_{i}$ ranges from 0 to 1 and $P_{i}$ is non- linearly related to $Z_{i}$. The logit of the unknown bionomial probabilities i.e the lorithms of the odds, are modeled as a linear functions of the $\mathrm{X}_{\mathrm{i}}$. The model is therefore estimated as:

$$
\operatorname{Logit}\left(\mathrm{P}_{\mathrm{i}}\right)=\mathrm{L}_{\mathrm{n}}\left[\frac{p 1}{1-p 1}\right]=\beta 0+\beta 1+\mathrm{X}_{\mathrm{i} 1} \mathrm{~B}_{\mathrm{k}} \mathrm{X}_{\mathrm{ik}}+\mu_{\mathrm{i}}
$$

The unknown parameters $\beta_{1}$ are usually estimated by maximum likelihood.

Thus, the model is explicitly expressed as:

$Z_{1}=\beta_{\mathrm{o}}+\beta_{1} \mathrm{x}_{1}+\beta_{2} \mathrm{x}_{2}+\beta_{3} \mathrm{x}_{3}+\beta_{4 \mathrm{x} 4}+\beta_{5} \mathrm{x}_{5}+\beta_{6} \mathrm{x}_{6}+\beta_{7 \mathrm{x} 7}+\mu$ Where:

$\mathrm{Z}_{1}=$ Poverty status of households

$\beta_{\mathrm{o}}=$ Constant term

$\beta_{1}=$ (1-7), vector of parameters to be estimated.

$X_{i}=$ Sex of the respondents $($ male $=1$ and female $=0$ )

$\mathrm{X}_{2}=$ Age of households

$\mathrm{X}_{3}=$ Household size

$\mathrm{X}_{4}=$ Educational status of the respondents

$\mathrm{X}_{5}=$ Child dependency ration (Ratio of 0-14 years to household size)

$\mathrm{X}_{6}=$ Average monthly savings $(\mathrm{N})$ of the respondents

$\mathrm{x} 7=$ marital status of the respondents (married $=1$ single $=0)$ Note: Divorce, Windows and widowers are also included).

\subsection{A Priori Expectation}

This refers to the expected behavior of the independent variables on the dependent variables based on economic theories. Thus, we have

$$
\mathrm{X}_{1}>0 \text { or } \mathrm{X}_{1}<0 ; \mathrm{X}_{2}>0 \text { or } \mathrm{X}_{2}<0 ; \mathrm{X}_{3}<0, \mathrm{X}_{4}>0 ; \mathrm{X}_{5}<0 ; \mathrm{X}_{6}>0 ; \mathrm{X}_{7}>0 \text { or } \mathrm{X}_{7}<0 \text {. }
$$

This means that the independent variables such as educational status $\left(X_{4}\right)$ and average monthly savings of the respondents $\left(\mathrm{X}_{6}\right)$ were expected to be positively significant to the dependent variable (Z1=poverty status of households) while household size $\left(X_{3}\right)$ and child dependency ratio $\left(X_{5}\right)$ were expected to have negative impact on the poverty status of households. It was also expected that the impact of sex $\left(X_{1}\right)$, marital status $\left(X_{7}\right)$ and age of the respondents $\left(\mathrm{X}_{2}\right)$ poverty status of households could be negative or positive.

\section{Data Analysis, Result and Discussion}

1.1. Sex: The analysis of the study revealed that $66.67 \%$ of beneficiaries of informal financial institutions are male while $33.33 \%$ of the beneficiaries constitute the female population. For the non-beneficiaries of IFIs the result showed that $56.19 \%$ of the respondents were female while $43.81 \%$ respondents.

The low membership of the female gender in IFIs in the study area could be attributed to the fact that household income in many rural communities in Nigeria is owned by men unlike the female. Women are therefore perceived to be more financial handicapped and may be unable to cope with the mandatory weekly or monthly savings required by IFIS.

1.2. Age: The result showed that $62.90 \%$ of the people who are beneficiaries of informal financial institutions in Konshisha Local Government Area fell within the age range of 36-60 years. This was followed by $29.62 \%$ representing those who were below the age of 35 years. The study also revealed that beneficiaries of IFIs who were above the age of 60 years were very few $(7.40 \%)$. This may be due to the fact that at the age of 61 years and above, many people are productively inactive and may not need to mobilize savings for business investment and other purposes.

For the non-beneficiaries of IFIs in the study area, the result showed that majority of the non- beneficiaries were within the age bracket of 35 years and below, followed by $39.04 \%$ which represent those within the age range of 3660 , while $20.00 \%$ constitute the non-beneficiaries that fell within the age range of 61 years and above. 
Table-1.Socio-Demographic Characteristics of the Respondents

\begin{tabular}{|c|c|c|c|c|c|}
\hline \multicolumn{2}{|c|}{ Characteristics } & \multicolumn{2}{|c|}{$\begin{array}{l}\text { Beneficiaries of informal financial } \\
\text { institutions (IFIS) }\end{array}$} & \multicolumn{2}{|c|}{$\begin{array}{l}\text { Non-beneficiaries of informa } \\
\text { financial institution (IFIS) }\end{array}$} \\
\hline & & Frequency & Percentage & Frequency & Percentage \\
\hline \multirow[t]{3}{*}{ Sex } & Male & 72 & 66.67 & 46 & 43.81 \\
\hline & Female & 36 & 33.33 & 59 & 56.17 \\
\hline & total & 108 & 100 & 105 & 100 \\
\hline \multirow[t]{4}{*}{ Age } & below 35 & 32 & 29.62 & 43 & 40.9 \\
\hline & $36-60$ & 68 & 62.96 & 41 & 39.04 \\
\hline & 61 and above & 8 & 7.41 & 21 & 20.00 \\
\hline & Total & 108 & 100 & 105 & 100 \\
\hline Marital & Married & 84 & 77.77 & 48 & 44.44 \\
\hline \multirow[t]{4}{*}{ Status } & Single & 17 & 15.74 & 37 & 35.24 \\
\hline & Divorced & 3 & 2.78 & - & \\
\hline & Widow/widower & 4 & 3.78 & 20 & 19.05 \\
\hline & Total & 108 & 100 & 105 & 100 \\
\hline \multirow{8}{*}{$\begin{array}{l}\text { Primary } \\
\text { Occupation }\end{array}$} & Civil servant & 18 & 16.67 & 2 & 1.90 \\
\hline & Business & & & & \\
\hline & Man/woman & 12 & 11.11 & - & - \\
\hline & Farming & 70 & 64.81 & 74 & 70.48 \\
\hline & Driving & 8 & 7.41 & & \\
\hline & Unemployed/ & & - & 29 & 27.62 \\
\hline & Schooling & - & & & \\
\hline & Total & 108 & 100 & 105 & 100 \\
\hline
\end{tabular}

Source: Field survey, 2014

1.3. Marital status: The study revealed that the beneficiaries of informal Financial Institutions under study are predominated by married people $(77.77 \%)$. $15.74 \%$ were single while $2.78 \%$ represent the beneficiaries that divorced. Further analysis showed that only $3.70 \%$ of the respondents were widows/widowers. For the nonbeneficiaries, the result showed that $44.44 \%$ of the respondents were married. This followed by $35.21 \%$ representing the single population while $19.5 \%$ of the respondents were widows/widowers. It also showed that none of the respondents divorced. The higher number of married people $(77.77 \%)$ in the informal financial institutions in the study area should not be surprise because married people are expected to have more financial responsibilities than their single counterpart and hence they involved in savings associations to access funds to cope with basic family needs such as health care, provision of food, education, clothing and other unforeseen occurrences.

1.4.Primary occupation: The study revealed that $64.81 \%$ of the respondents who are beneficiaries of Informal Financial Institutions engaged in farming as their primary economic activity, $16.67 \%$ of the respondents, were civil servants, $11.11 \%$ were business men/women while $7.41 \%$ represent those who were drivers. Further analysis showed that none of the beneficiaries of Informal Financial Institutions interviewed were either unemployed or schooling.

Similarly, farming was also identified as the major economic activity of non-beneficiaries of IFIs in the study area constituting about $70.48 \%$ of the population interviewed. This is followed by $27.62 \%$ respondents who were Civil Servants. The result showed clearly that farming is the main economic activity of both beneficiaries (64.80\%) and non-beneficiaries $(70.48 \%)$ of IFIs is the study area. This must not be unconnected to the fact that Konshisha Local Government is a rural community whose inhabitants are predominantly farmers.

\subsection{Socio-Economic Attributes of the Respondents}

The socio-economic attributes that are of important to this research work include household size, household consumption expenditure, education status of households, child dependency ratio and average monthly savings as presented in the table below.

2.1. Household size: The study revealed that majority of the beneficiaries of IFIs in Konshisha Local Government Area had a household size of 5-7 persons, followed by those with household size of 8-10 persons representing $28.70 \%$ while $24.7 \%$ of the respondents constitute the beneficiaries of IFIs who had maximum of four persons in their households. The result further showed that only about $12.04 \%$ of the respondents had a larger household size of 11 persons and above. For the non-beneficiaries of IFIs, the analysis showed that $35.23 \%$ of the respondents had a household size of 5-7 persons as in the case of beneficiaries of IFIs. This was followed by $33.33 \%$ $20.95 \%$ and $10.48 \%$ representing non-beneficiaries of IFIs who had household size of 8-10 persons, 11 persons and above and 0-4 persons respectively. Since the household size of non- beneficiaries is relatively higher than that of beneficiaries, the incidence of poverty will also be more among the non- beneficiaries of IFIs in the study area. This is because house size of respondents negatively influences their poverty status.

2.2. Education Status: The study showed that household heads with secondary education constitutes the highest percentage of 44.44 among beneficiaries of IFIs interviewed. This was followed by those who acquired primary education $(29.63 \%)$, tertiary education $(18.51 \%)$ and finally those who had no formal education representing only $7.40 \%$.

On the contrary, the analysis of the education status of the non-beneficiaries of IFIs indicated that $49.52 \%$ of the respondent lack formal Education while $32.38 \%, 16.19 \%$ and $1.90 \%$ represent respondents who acquired primary, secondary and tertiary education respectively. The result Cleary showed that illiteracy is higher among nonbeneficiaries of IFIs $(49.52 \%)$. than in the beneficiaries of IFIs (7.40\%). This implies that lack of formal education may be accountable for high occurrence of poverty among non-members of IFIs in the study area since the importance of education in self sustenance cannot be overemphasized. 
Table-2.Socio-Economic Attributes of the Respondents

\begin{tabular}{|c|c|c|c|c|c|}
\hline \multirow[t]{2}{*}{ Attributes } & & \multicolumn{2}{|c|}{$\begin{array}{l}\text { Beneficiaries } \text { of } \text { Informal } \\
\text { Financial } \\
\text { (IFIs) }\end{array}$} & \multicolumn{2}{|c|}{$\begin{array}{lr}\text { Non-beneficiaries } & \text { of } \\
\text { Informal } & \text { Financial } \\
\text { Institutions (IFIs) } & \end{array}$} \\
\hline & & $\begin{array}{l}\text { Frequenc } \\
\mathbf{y}\end{array}$ & Percentage & Frequency & Percentage \\
\hline $\begin{array}{l}\text { Household } \\
\text { Size }\end{array}$ & $\begin{array}{l}0-4 \\
5-7 \\
8-10 \\
11 \& \text { above } \\
\text { Total }\end{array}$ & $\begin{array}{l}26 \\
38 \\
31 \\
13 \\
108\end{array}$ & $\begin{array}{l}24.07 \\
35.19 \\
28.70 \\
12.04 \\
100\end{array}$ & $\begin{array}{l}11 \\
37 \\
35 \\
22 \\
105\end{array}$ & $\begin{array}{l}10.48 \\
35.24 \\
33.33 \\
20.95 \\
1000\end{array}$ \\
\hline Education & Non-formal & & & & \\
\hline Status & $\begin{array}{l}\text { Education } \\
\text { Primary education } \\
\text { Secondary school } \\
\text { Tertiary } \\
\text { institution } \\
\text { Total }\end{array}$ & $\begin{array}{l}8 \\
32 \\
48 \\
20 \\
108 \\
\\
2\end{array}$ & $\begin{array}{l}7.40 \% \\
29.63 \\
44.44 \\
18.51 \\
100 \\
1.85\end{array}$ & $\begin{array}{l}52 \\
34 \\
17 \\
2 \\
105 \\
12\end{array}$ & $\begin{array}{l}49.52 \\
32.38 \\
16.19 \\
1.90 \\
100 \\
11.43\end{array}$ \\
\hline Household & $\begin{array}{l}\text { Below } 55000 \\
56000-100,000\end{array}$ & & $\begin{array}{l}11.11 \\
16.67\end{array}$ & $\begin{array}{l}48 \\
20\end{array}$ & $\begin{array}{l}45.71 \\
19.5\end{array}$ \\
\hline Consumption & $\begin{array}{l}100001-155000 \\
156000-200000\end{array}$ & $\begin{array}{l}34 \\
42\end{array}$ & $\begin{array}{l}37.48 \\
38.89\end{array}$ & $\begin{array}{l}15 \\
10\end{array}$ & $\begin{array}{l}14.29 \\
9.52\end{array}$ \\
\hline Expenditure & $\begin{array}{l}200001 \& \text { above } \\
\text { Total }\end{array}$ & 108 & 100 & 105 & 100 \\
\hline /annum & $\begin{array}{l}0-2 \\
3-4\end{array}$ & $\begin{array}{l}48 \\
34 \\
26\end{array}$ & $\begin{array}{l}44.44 \\
31.48 \\
24.07\end{array}$ & $\begin{array}{l}29 \\
37 \\
39\end{array}$ & $\begin{array}{l}27.62 \\
35.24 \\
37.14\end{array}$ \\
\hline Child & $\begin{array}{l}5 \text { and above } \\
\text { Total }\end{array}$ & 108 & 100 & 105 & 100 \\
\hline Dependency & Below 500 & $\begin{array}{l}16 \\
31\end{array}$ & $\begin{array}{l}14.81 \\
28.70\end{array}$ & $\begin{array}{l}\text { No Monthly } \\
\text { Savings }\end{array}$ & $\begin{array}{l}\text { No } \\
\text { Percentage. }\end{array}$ \\
\hline Ratio & $\begin{array}{c}501-2000 \\
2001-3500\end{array}$ & $\begin{array}{l}24 \\
23\end{array}$ & $\begin{array}{l}22.22 \\
21.29\end{array}$ & & \\
\hline $\begin{array}{l}\text { Average monthly } \\
\text { Savings }\end{array}$ & $\begin{array}{l}3501-5000 \\
\text { Above-5001 } \\
\text { Total }\end{array}$ & $\begin{array}{l}14 \\
105\end{array}$ & $\begin{array}{l}12.96 \\
100\end{array}$ & & \\
\hline
\end{tabular}

\subsection{Household consumption-expenditure/Annum (N):}

The result of the study revealed that majority of the members of IFIs (38.89\%) had estimated annual consumption expenditure of 200001 and above, followed by those with annual consumption expenditure of N156000-200000 constitution $31.48 \%$ of the respondent while $16.67 \%, 11.11 \%$ and $1.85 \%$ representing respondents with estimated household consumption-expenditure of N101000-155000 and below 55000 naira respectively.

Further result of the analysis indicated that majority of the non-beneficiaries of IFIs $(45.71 \%)$ in the study area had a lower household consumption-expenditure of N56000-100000 per annum. This followed by 19.05\%, 14.29\% and $9.52 \%$ constituting respondents with household consumption-expenditure of bellowed 55000. The result showed clearly that beneficiaries of IFIs in the study area had higher household consumption-expenditure than those who were non-beneficiaries of IFIs. This implies that they are likely to be better off and less poor than non-beneficiaries of informal financial institutions in the study area.

2.4. Child Dependency Ratio: The study revealed that about $44.44 \%$ of the beneficiaries of IFIs had $0-2$ children as dependents. This followed by $31.48 \%$ (3-4 children) and $24.07 \%$ representing the respondents with high child dependency ratio of 5 children and above.

For the household made up of non-beneficiaries of informal financial institutions, the study showed that $37.14 \%$ of the respondents had the highest child dependency ratio of 5 children and above. This was closely followed by those with 3-4 children and 1-2 children representing $35.24 \%$ and $27.62 \%$ of the respondents respectively.

2.5. Average Monthly Savings: The result of the study revealed that $28.70 \%$ of the respondents contributed an average monthly savings of (501-2000). This was followed by members who saved between N2001-3500, N35015000 and above N5001 representing 22.24\%, $21.29 \%$ and $12 \%$ of the respondent respectively. The analysis further reveals that only $14.8 \%$ of the respondents had a monthly savings of 500 and below.

Table-3. Poverty Incidence, Depth and Severity among Households in Konshisha Local Government of Benue State based on Minimum Consumption-Expenditure of 63875 Naira per adult per Annum. (Poverty line)

\begin{tabular}{l|l|l|l|l}
\hline IFIs & $\begin{array}{l}\text { Number of } \\
\text { poor people }\end{array}$ & $\begin{array}{l}\text { Incidence } \\
\text { poverty }\left(\mathbf{P}_{\mathbf{0}}\right)\end{array}$ & $\begin{array}{l}\text { Depth of } \\
\text { poverty }\left(\mathbf{P}_{\mathbf{1}}\right)\end{array}$ & $\begin{array}{l}\text { Severity of } \\
\text { poverty }\left(\mathbf{P}_{\mathbf{2}}\right)\end{array}$ \\
\hline Beneficiaries of IFIs & 69 & 63.39 & 0.6371 & 0.6352 \\
\hline Non-beneficiaries of IFIs & 82 & 78.09 & 0.7881 & 0.7762 \\
\hline
\end{tabular}

Source: Field Survey, 2014

Table 3: shows the poverty incidence $\left(\mathrm{P}_{0}\right)$, Depth $\left(\mathrm{P}_{1}\right)$ and severity poverty $\left(\mathrm{P}_{2}\right)$ of beneficiaries and nonbeneficiaries of IFIs in the study area using Foster-Greer-Thorbecke (FGT index) as defined in the methodology. 
The study revealed that there was high incidence of poverty in both beneficiaries of IFIs $(63.89 \%)$ and nonbeneficiaries (78.0\%). This result is in line with the findings of World Bank (1996) that rural areas in Nigeria accounted for $66 \%$ of incidence of poverty, $72 \%$ of the depth of poverty and $69 \%$ of the extreme poor.

However, non-beneficiaries of IFIs in the study area had a deeper poverty depth of $0.788 \%$ than beneficiaries of IFIs with poverty depth of 0.6371 . The severity of poverty was also found to be higher among non-beneficiaries of IFIs (0.7762) than in beneficiaries of IFIs (0.6352). The Study also showed clearly that the incidence of poverty was higher among non-beneficiaries of IFIs than those who engaged in savings with IFIs.

The higher incidence $\left(\mathrm{P}_{\mathrm{o}}\right)$, depth $\left(\mathrm{P}_{1}\right)$ and severity of poverty among non-beneficiaries of IFIs implies that they are worse off in terms of welfare (standard of living) than those who are members of IFIs in the study area. This means that informal financial institutions existing in Konshisha local government area have helped its beneficiaries to reduce their poverty level.

Table-4. Summary of Regression Analysis for Determinants of Poverty Status for Beneficiaries and Non-Beneficiaries of Informal Financial Institutions.

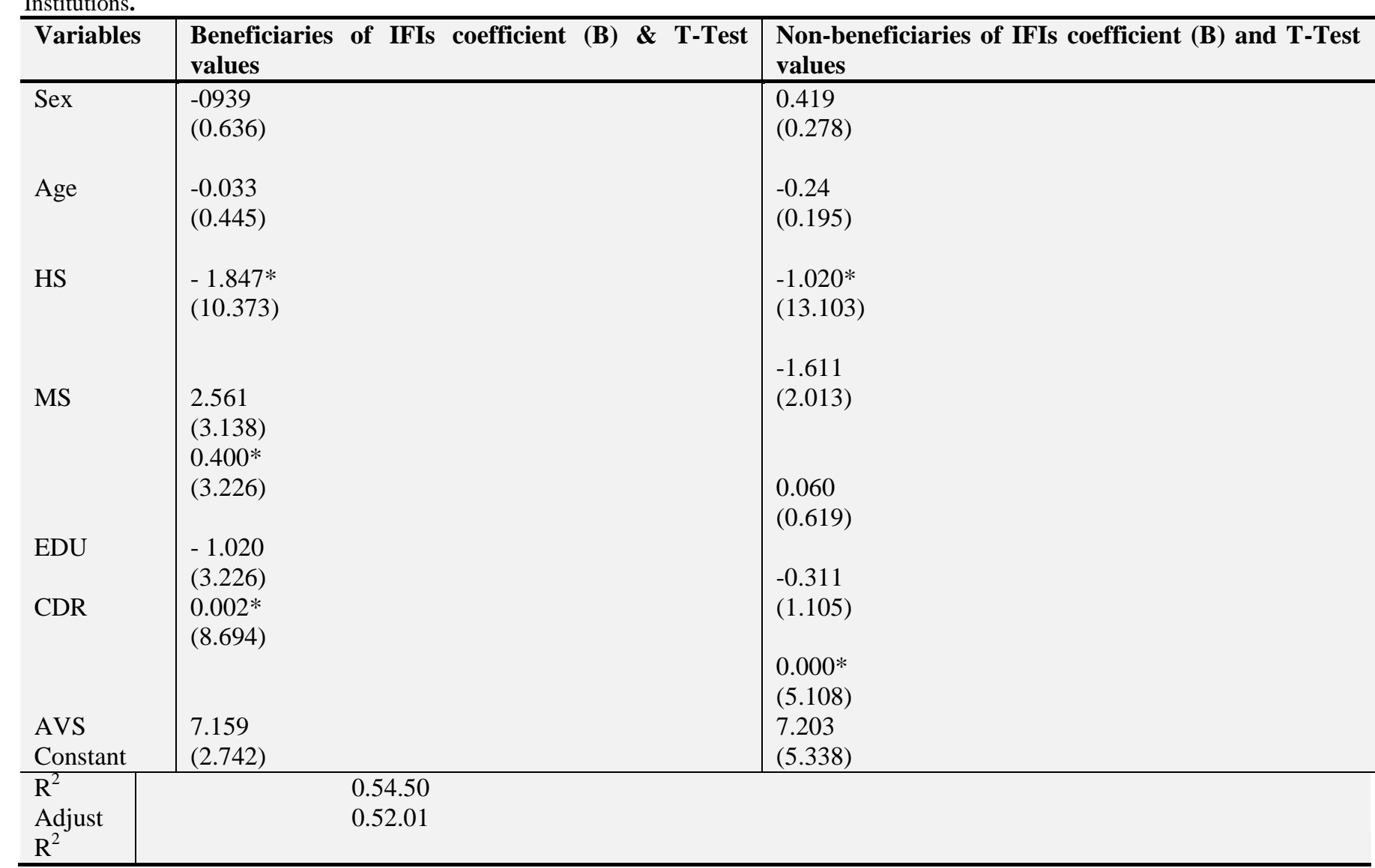

Source: Data analysis, 2014.

Values in parenthesis represent T-test at $5 \%$ level of significant, while the single asterisks $\quad(*)$ indicate values that are significant at same level.

A general look at the model shows that it has an $\mathrm{R}^{2}$ of 0.54 . This shows that $54 \%$ variation in the dependent variable (poverty status of the respondents) is explained by the explanatory variables (socio-economic attributes of the respondents) in the model while the error term takes care of the remaining $46 \%$ which are variables in the study that cannot be included in the model because of certain qualitative features.

Details of the analysis showed that two of the variables regressed namely; education $(0.400$ and 0.060$)$ and average monthly savings (0.002) and 0.000) were estimated positive both in beneficiaries and non-beneficiaries of IFIs as respectively shown in the parentheses above. The result also revealed that three of the exogenous variables regressed estimated negative both in beneficiaries of IFIs and non-beneficiaries of IFIs. These include; child dependency ratio (-020 and -0.311$)$, household size $(-1.847$ and -1.020$)$ and age $(-0.033$ and -0.24$)$ respectively (0.419) among the non-beneficiaries of IFIs but was negative in $(-0.939)$ beneficiaries of IFIs, while marital status was found to have positive coefficient (2.561) in beneficiaries of IFIs but was negative (-1.611) among the nonbeneficiaries of IFIs.

The positive values of the coefficient of variables in both beneficiaries and non-beneficiaries of informal financial institutions shows that higher values of these variables tends to increase the likelihood for better welfare and thus reduction in poverty status while the negative values of the variables on the other hand implies that a higher value tends to decrease the probability of better welfare and thus increase the poverty status of people in both beneficiaries and non-beneficiaries of IFIs.

For instance, education of household had positive estimates $(0.400$ and 0.060$)$ for both beneficiaries and nonbeneficiaries of informal financial institutions respectively but was only significant for beneficiaries of IFIs at 5\% level because members of IFIs are more educated than non-beneficiaries of the institutions. This implies that the likelihood for poverty reduction among beneficiaries of IFIs is higher than in non-members of IFIs.

The result also showed that household size had negative values of estimates (-1.8.47 and -1.020) for both beneficiaries and non-beneficiaries of IFIs and were all significant at 5\% levels. This is in line with the a prior expectation that household size negatively influence the poverty status of an individual as well as his welfare due to severity of dependence effect as households get larger. This implies that for every additional individual in a household, poverty will increase by-1.847 and -1.020 in both beneficiaries and non beneficiaries of informal 
financial institutions respectively but it will be higher among non-beneficiaries of IFIs base on the values given above.

The average monthly savings of individual household was found to be positively significant in both beneficiaries (0.020) and non beneficiaries (0.000) of informal financial institutions at $5 \%$ level of significant.

This is in consonance with the apriori expectation that the higher the savings of an individual household, the lower the incidence of poverty. This is because savings is expected to be channeled into investment. This further implies that for every increase in savings of households by one naira, poverty is expected to be reduced by 0.0021 and 0.000 in beneficiaries and non beneficiaries of informal financial institutions respectively.

This result further justified why respondents who benefited from IFIs in Konshisha local government area were found to be less poor than non-beneficiaries.

Further analysis also revealed that child dependency ratio was negative in conformity with the apriori expectation for both beneficiaries of IFIs (-1.020) and non-beneficiaries of IFIs (-0.311), respectively. However, the influence of child dependency ration on poverty status of both beneficiaries and non beneficiaries of IFIs was insignificant in the study area at $5 \%$ level.

Similarly, the study further revealed that the influence of sex, age and marital status on poverty level of the inhabitants of Konshisha local government was found to be insignificant at $5 \%$ level.

Table-5. T-test of Difference in Mean of Real household consumption-Expenditure of Beneficiaries and Non-Beneficiaries of Informal Financial Institutions in Konshisha Local Government Area of Benue State.

\begin{tabular}{l|l|l|l|l|l|l|l}
\hline Informal Financial Institutions & No. of resp. & Mean (N) & St. deviation & Mean difference & D.F & T & Sig \\
\hline Beneficiaries of IFIs & 108 & 59828.6 & 52209.81 & $27728.60^{*}$ & 155.11 & 4.96 & 0.00 \\
\hline Non-beneficiaries of IFIs & 105 & 32100 & 2.5159 .0 & & & & \\
\hline
\end{tabular}

Source: Field survey, 2014.

Single asterisk $(*)=\mathrm{t}$-test of difference significant at $1 \%$ level.

Table 5 shows that 108 beneficiaries of informal financial institutions in Konshisha local government area have mean household consumption expenditure of N59828.60 per annum. While that of non-beneficiaries was 32100 Naira per annum. This gives a significant mean difference of 27728.60 Naira at $1 \%$ level. The result shows clearly that beneficiaries of Informal Financial Institutions have more real household consumption expenditure than nonbeneficiaries in the study area. Since individual's consumption expenditure depends on their income, it therefore implies that beneficiaries of IFIs in the study area have more income than non-beneficiaries. This is attributed to the fact that the existence of informal financial institutions in the study area enables members to access funds to meet their various needs thereby reducing their poverty level.

A general look at this result thus conformed with the views of Aryeetey (1994); Noah et al. (2009) and Ijaiya (2002) who reported that informal financial institutions has helped in mobilizing savings which are in turn used as working capital to restock supplies which enables beneficiaries to expand their output and earn a stream of profit, thereby providing a significant source of income to individual household which reduces their level of poverty.

\subsection{Conclusion and Recommendations}

The study revealed that informal financial institutions are an integral part of rural economic life and an alternative source of credit for rural people. Their existence in Konshisha local government area has contributed significantly towards poverty reduction through the disbursement of micro loans to their members for productive investment.

Given the failure of most Nigerian government rural financial intervention programmes, the researchers therefore recommended that money market development policies should be tailored towards developing the informal financial institutions in rural areas in order to expand their scope of meeting the financial needs of the rural dwellers particularly in Konshisha local government area to reduce poverty. For instance, the government can augment the low-income earnings of members by making soft loans (loans with very low interest) available to members through informal financial institutions in which (IFIs) they belong.

Equally recommended is that drastic efforts should be taken by all the stakeholders in the education sector to ensure that quality and affordable formal education is provided to all the inhabitants of Konshisha local government area. This is because education is a social capital and it has impacted positively on poverty reduction level of the people in the study area.

\section{References}

Ajegi, S.O., 2004. Determining the poor against the background of local situation and circumstances. A Paper Presented at Organizational Workshop of National Poverty Eradication Programme at Benue Hotel Makurdi, Nigeria.

Aliyu, A., 2002. Implementation progress beport background, structure, achievement and problems of NAPEP. A Paper Presented at a OneDay Special Presidential Retreat for Permanent Secretaries in Abuja, Nigeria.

Appleton, S., 2001. Poverty in Yuganda; 1999/2000 preliminary estimate from the UNHS. Nottingham: University of Nottingham, Mimeo, Working Paper No. WPS/99/22.

Aryeetey, E., 1994. Rural finance in Africa: Institutional development and access for the poor. Nottinghan: University of Nottinghan. In Bruno, M. and Pleskovic, B. (Eds). Annual World Bank Conference in Development Economic 1996, Washington, D.C.

Awolowo, O., 1981. Path to Nigeria greatness. Enugu: Fourth Dimension Publishers.

Federal of Statistics (F.O.S), 1999. Poverty and agricultural sector in Nigeria: Poverty incidence of farmers by region. Nigeria: F.O.S. Head Office Abuja. pp: 4-33.

Foster, J., J. Greer and E. Thorbocke, 1984. A class of the decomposable poverty measure. Economist, 52(3): $761-766$.

Grootaert, C. and J. Braithwaite, 1998. Poverty correlate and indicator, and based targeting in Eastern Europe and former Soviet union: World Bank Policy Research Working Paper No.1942.

Ijaiya, G.T., 2002. The role of informal sector in minimizing poverty in Ilorin metropolis. Unpublished PhD Thesis. Department of Economics, Usman Dan Fodiyo University, Sokoto, Nigeria.

Mckinnon, R., 1973. Money and capital in economic development. 1st Edn., Washington DC. USA: Broking Institution.

Noah, Y.I., I. Gafar and A.I. Muftau, 2009. Informal finance institutions and poverty reduction in the informal sector of Offa Town, Kwara State: A case study of rotating savings and credit associations. Journal of Social Science, University of Ilorin, 20(1): 71 - 81. 
Ramakrishma, G. and A. Demeke, 2002. An empirical analysis is of food insecurity in Ethiopia: The case North Wollo. Council for the Development of Social Science Research in Africa: Addis Ababa. Africa Development, 27(1 \& 2): 127-143.

Shaw, E.S., 1973. Financial deepening in economic development. New York: Oxford University Press.

World Bank, 1990. World bank development. Reporting poverty. New York: Oxford University Press.

World Bank, 1996. Poverty in the midst of plenty: The challenge of growth with inclusion. A World Bank Poverty Assessment Report, Population of Human Research Division, World Bank.

\section{Bibliography}

Aryeetey, E., 1998. Informal finance for private sector development in Africa. African Development Bank Economic Research Paper. No. 41. Cenral Bank of Nigeria, C.B.N., 2000. Changing structure of Nigerian economy and implication for development. Lagos: Realm Communications Ltd.

World Bank, 2001. Attacking poverty: World development report. New York: Oxford University Press. 